\title{
The characteristics analysis of torque and rotation speed of working unit of branch grinder - introductory research
}

\author{
Lukasz Warguła ${ }^{1, *}$, Jarosław M. Adamiec ${ }^{1}$, Konrad J. Waluś ${ }^{1}$, Piotr Krawiec ${ }^{1}$ \\ ${ }^{1}$ Poznan University of Technology, Chair of Basic of Machine Design, Piotrowo Street 3, \\ 60-965 Poznan, Poland
}

\begin{abstract}
Carrying out a realistic research on working units of machines that grinder waste coming from tree and bush trimming requires designing machines that would be more efficient. It is neccesary both to introduce the analysis of already existing solutions as well as searching for innovative ones that would result in the increase of efficiency, lowering the costs and time needed as well as lower exhaust emission into the atmosphere. The results presented below will be used for the following purposes: the analysis of grinding process that supplies data to cunstruct simulating models that reflect the real working conditions of grinding machines. The results of the experiments will allow to estimate the influence of construction featrures, including the ones connected with automatisation. The importance of the carried out research is also applicable to the analisys of influence of grinding process on the form of flakes that result from the process, energy consumption. It also allows to make conclusions leading to the improvement of the processes that use grinded mass. The construction specifity of ths kind of machines and their working principles results from the fact, that the cutting process they perform concerns orthotropic plant material that has inhomogenic structure and physical-chemical properties requires further analysis. The article presents the construcion of a research stand designed to record the characteristisc of changes of the torque and rotation speed of working unit of mill chopper type MQS2800 Macalister. The introductory research results presented below point out that depending on the position of the sample (along the grain) against the mill chopper significantly influences on the form of generated changes of the torque. The research stand that has been designed and constructed allows the analysis of both construction features of the chopper as well via the assessment of grinding process also separte paremeters of processed wood.
\end{abstract}

Keywords: wood chipping process; actual research findings; wood chips; wood shavings; kinematics of the wood chipper; dynamics of wood chopping processes; processing of green waste

\footnotetext{
* Corresponding author: lukasz.wargula@put.poznan.pl

Reviewers: Grzegorz Domek, Janusz Mielniczuk
} 


\section{Introduction}

The forestry, orchard, horticulture, energy and urban greenfield or roadside industries are constantly looking for new, more effective methods of tree care [1-4]. Many of these tasks can be improved by introducing automated systems or modifying existing ones $[5,6]$. One of the important aspects of the design and modeling process of new efficient constructions is knowledge of the actual operating conditions of the equipment. Literature review indicates that there is a lack of real results of dynamic research of chipping process. The dynamic characteristics of the periodically-variable rotational speed and torque that are generated in these processes are necessary for describing the input conditions of simulation models that reproduce actual working conditions. The research has been done to help model the construction of the chipping machines, both the working unit and the drives, clutches and gear units. Testing the existing construction allows for a better understanding of the processes involved and supports their automation, which is the main reason for the increased efficiency of these devices [7-9].

One of the most important issues in the abovementioned industries, but also in households, is the processing of waste generated by them [10]. Branches as waste from the trees and shrubs' care or their cultivation as sources of energy such as willow (biofuel), require proper treatment prior to application. Depending on the application i.e. directly as fuel or biomass; Energy is obtained by: pyrolysis, estimation or fermentation [11, 12]. Chips are also used as compost, mulch [13] and chipboard raw material [14]. Additionally chipping branches facilitate their transport [15], storage and exploitation in the aforementioned processes.

Chipping machines for branches, leaves or similar material use differentiated systems and grinding systems. Machines such as breaker row, crushers, disintegrators, cutters or mills are used for mechanical shredding of solids,. Woodchips are mainly used for the processing of green waste, due to way of use also referred to as recyclers. These are machines for chipping branches, and in case of large machines, even for chipping whole trees. Another division based on application is the division into household chippers and industrially used. Among the first group there are self-propelled wood-chippers or combustion-driven wood chippers, and chippers driven by farm tractors. The second group is professional woodchips, which are divided into: self-propelled wheeled machinery, selfpropelled machinery and built-in machines. Due to the kinematics of the cutting mechanism, a number of chipper constructions can be distinguished: discs, beaters, screws, cylinders, drums, otherwise known as mills, when electrically driven for home use. In 2006, Naimi, Sokhansanj, Mani, Hoque, Bi, Womac, Narayan [16] conducted a review of the available chipper constructions together with their energy consumption studies.

The specificity of the construction of such devices and operating principles is due, among other things, to the fact that their cutting process involves orthotropic plant materials whose structure is heterogeneous, and the physicochemical properties are not fully identified [17-21].

An important aspect in the construction of machines is the construction of devices characterized by low energy consumption of work processes. It contributes to the development of a variety of cutting tool designs that are still being tested for optimization. Very often already used and well-know constructions due to technological development undergo structural changes, which lead to improvement of the characteristics of these structures in many aspects at the same time. Krajnc and Dolsak [22] conducted real and simulated drum chipper experiments in 2013 , they controlled the material, construction and technological parameters influencing the crushing process. In addition, the thermal characteristics of the generated whirls were investigated, indicating that the chipping process that generates more dust reduces the energy properties of the raw material. In 2012, 
Merhar and Bučar [23] presented the actual results of the wood cutting force survey indicating the variable value of this parameter. The cause of this phenomenon is the fracture of the workpiece right in front of the cutting edge. In the articles of 2010, Nati and Spinelli [24] and Nati, Spinelli and Fabbri [25] examined the actual working conditions of shredders by examining fuel consumption, analyzing the impact of blade wear and the type of shredded wood on this parameter. A year later (2011) Spinelli, Magagnotti, Paletto and Preti [26] presented results of studies on the impact of wood characteristics such as species, moisture and parts of the processed tree on the quality of the chipped product and fuel consumption. Conducting research on actual work units helps to design more efficient constructions, and exploration of obtained wood chips results conclusions leading to improved processes utilizing comminuted mass.

The subject of consideration is the scientific and technical importance of the problem of determining the torque characteristics and the rotational speed of the working unit in the process of shredding. It will allow to determine the nature of the load generated and the correct choice of powertrain and executive system of shredding process. The article presents a modern research stand together with experimental results.

\section{Research stand}

The research was carried out at a research station that allows research on the processes of chipping wood. The station was constructed on the basis of the MQS2800 Macalister electric wood chipper. A hinge assembly consisting of an electric motor, a belt transmission, a planetary gear and a working member was excluded. Research on the kinematic and dynamic characteristics of the chipping process required the development of a separate unit with a measuring device (Figure 1). The torque measurement was performed using a universal torque gauge designed by Chair of Basic of Machine Design, Poznan University of Technology. A MEGATRON MOB 2500/5/BZ/N encoder was used to record instantaneous changes in the angular speed of the working shaft of the shredding member. The results of torque and angular velocity measurements were recorded in the author's computer program, which is an integral part of the research stand.

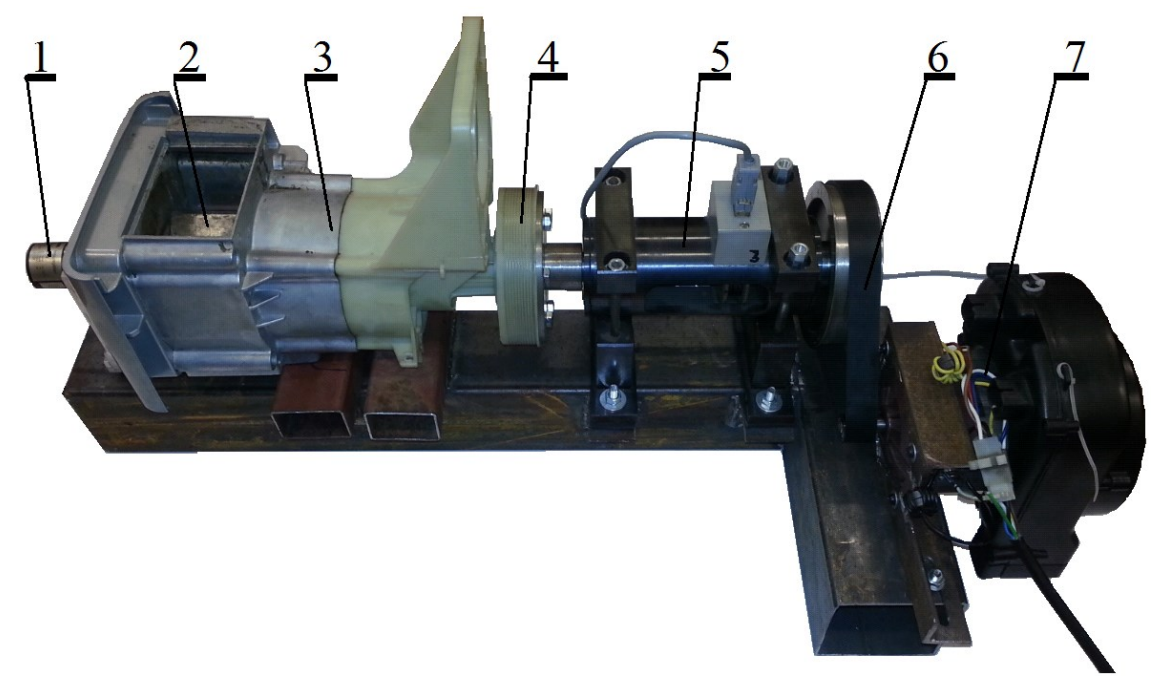

Fig. 1. Research stand that records torque and rotational speeds characteristics during chipping processes: 1- encoder; 2-working unit; 3 - planetary gear unit; 4-solid coupling; 5-torquemeter; 6-belt transmission; 7 -drive engine 


\section{Results of preliminary tests}

Preliminary tests of the kinematic and dynamic characteristics of the working unit of the chipper has been carried out, determining its torque and rotational speed. In the first attempt, these values were measured without load on the working unit (Figure 2).

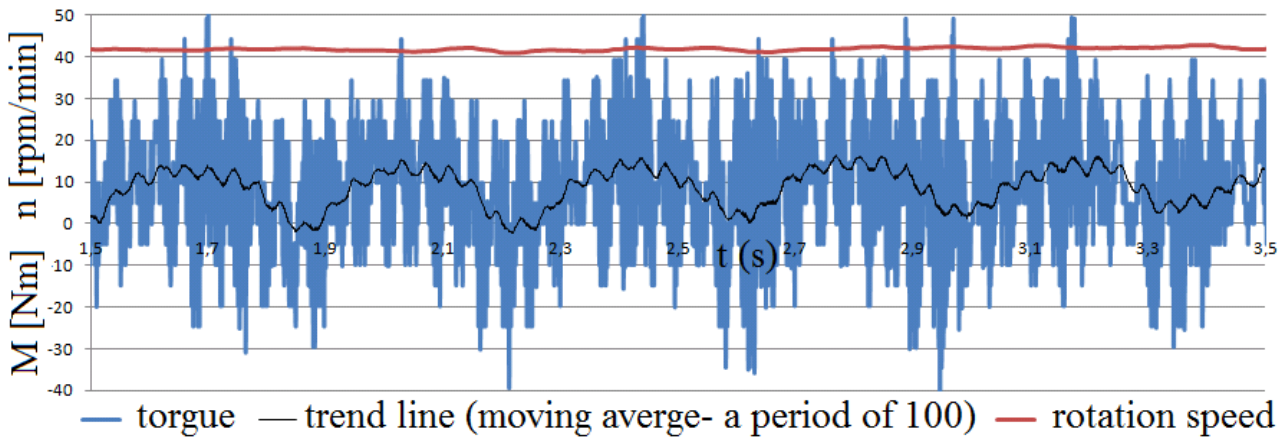

Fig. 2. Torque and rotation speed characteristics as a function of time, without load on the working unit

In the second and third set of tests, the torque value and the rotational speed generated during the pine beam shredding with a cross section of $18 \times 18$, with a moisture content of $21.5 \% \mathrm{MC}$ were measured. The sample was chipped in two positions, due to the position of the tree grains. The cutting characteristics of the sample of the tree grains arranged perpendicularly to the cutting edge are shown in Figure 3, and parallel in Figure 4. In addition, the characteristics of the chipper workings phase are as follows: work without load $\mathrm{a}$, transition $\mathrm{b}$ and chipping $\mathrm{c}$.

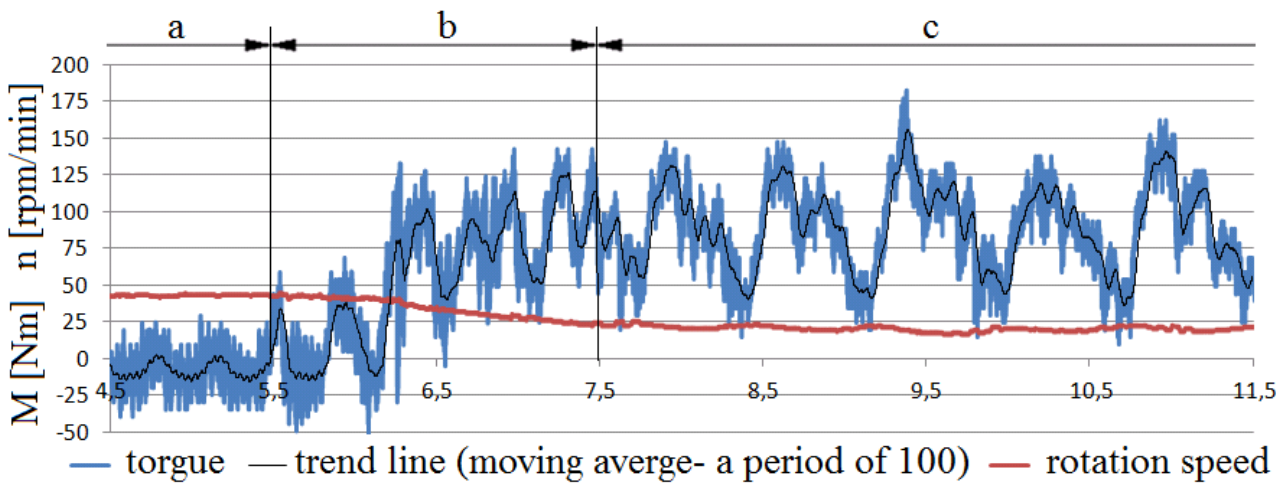

a) no-load operation; b) transition process; c) shredding

Fig. 3. Torque and rotation speed characteristics as a function of time, chipper working unit in different phases of work, test 2 


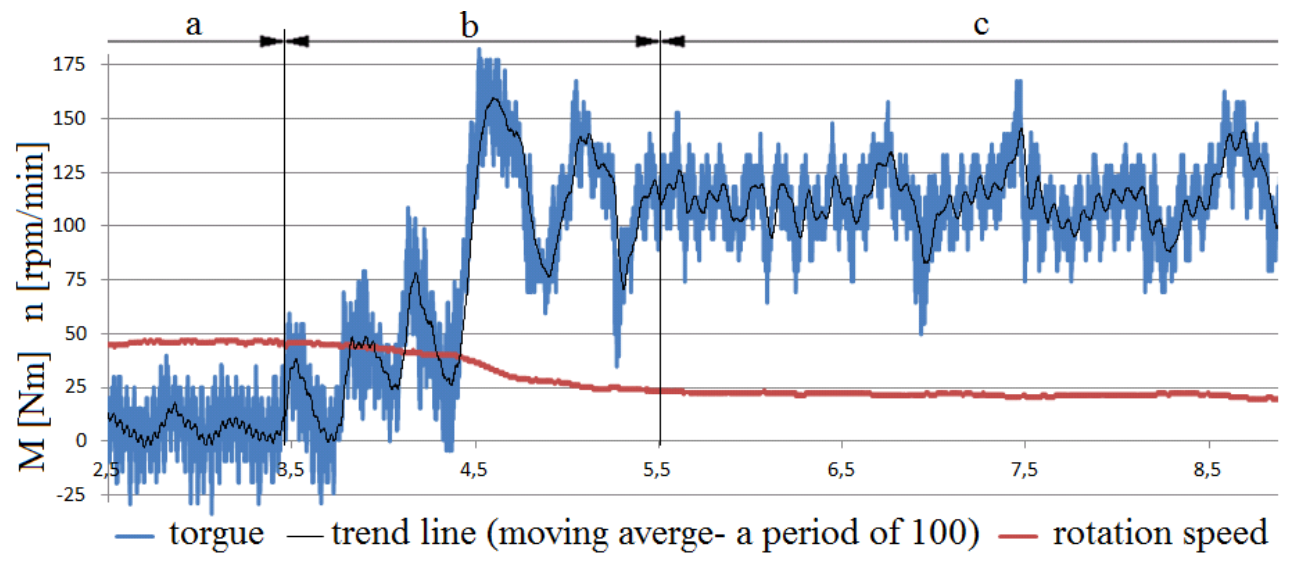

a) no-load operation; b) transition process; c) shredding

Fig. 4. Torque and rotation speed characteristics as a function of time, chipper working unit in different phases of work, test 3

\section{Analysis of results}

Actual dynamic characteristics of the rotary speed and torque of the MQS2800 Macalister chipper working unit are characterized by variability and signal distortion. However, the main character of the change is possible to be defined.

An unloaded working unit generates a constant speed of about $45 \mathrm{rpm}$. The generated torque oscillates between 0 and $10 \mathrm{Nm}$, due to the structure which is unbalanced as shown in Figure 2, and is additionally exposed to imbalances associated with blade defects created during exploitation.

The process of chipping is characterized by unique characteristics that result from the process of cutting orthotropic plant materials whose structure is an anisotropic. During the chipping of the aforementioned sample, the rotational speed decreases almost twice and the torque in the extremes reaches more than $150 \mathrm{Nm}$ (Figures 5 and 6). However, due to the position of the tree grains during the chipping process, differences in the main character of the changes can be observed. The process of chipping when the tree grains of the workpiece is positioned as shown in Figure 5 generates a significantly different nature than the position of the sample in Figure 6. The first position of the sample generates a dynamic increase in the load which, after exceeding the extremity, significantly decreases the generated resistance up to $40 \mathrm{Nm}$. The reason for such a characteristic is the cracking of the wood which in this position is prone to layering, while generating evenly shredded chips. The second position of the sample to be processed results in a milder increase in the maximum torque and offload. However, in this position the minimum torque does not drop below $60 \mathrm{Nm}$ and the chip is not cut. The collected characteristics indicate that there is no significant cracking of the material at this position in front of the cutting edge. In addition, during this process the characteristics may also be affected by the fact that some of the fragmented parts may return to the work area and be re-fragmented. For the principal character of the changes (Figs. 5 and 6), the most common characteristics of the cut material were chosen for the two successive blades of the cutter. 


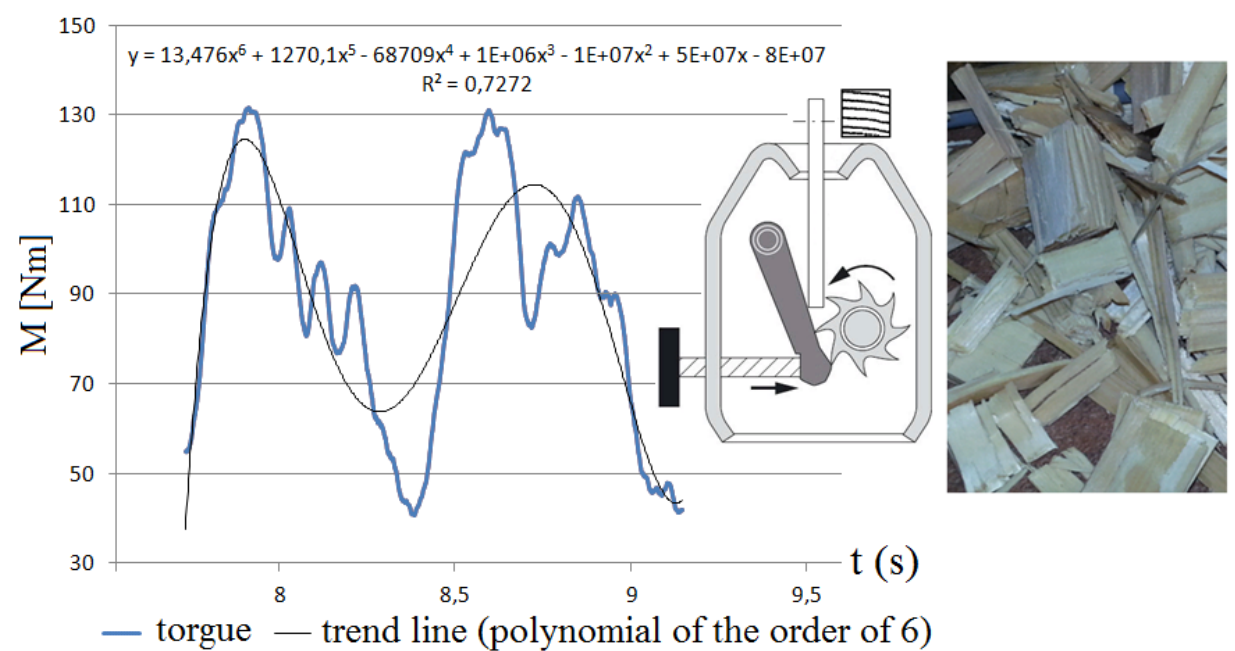

Fig. 5. Characteristics of the main character of torque changes, due to the location of the sample (I) and generated chips

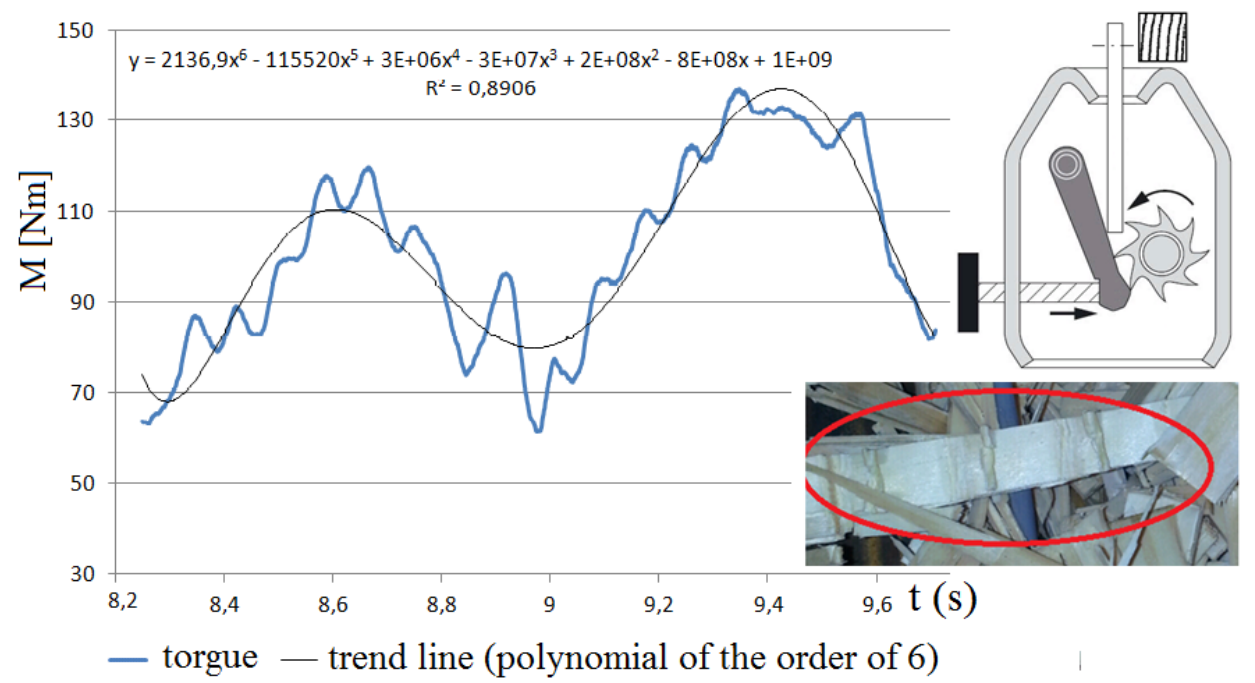

Fig. 6. Characteristics of the main character of torque changes, due to the location of the sample (II) and generated chips

\section{Conclusions}

Experimental preliminary research have shown that the constructed research station enables the study of the characteristics of the MQS2800 Macalister chipper working unit, a representative of electric chippers for use in households. The collected characteristics also allow the analysis of the chipping samples not only within their maximum strength values, but also in the processes taking place during cutting. The actual characteristics of the generated torque and the rotational speed can be used in the analysis of the strength of the structure. Modeling simulations of shear component life, i.e., working unit, transmission or drive loaded periodically-variable. These characteristics also allow us to evaluate the 
efficiency and energy consumption of this type of construction, together with the possibility to evaluate the generated raw material.

\section{References}

1. B. Fortuna-Antoszkiewicz, K. Gadomska, K. Gadomski, Decoration and maintenance of green areas (original title in Polish: Urzadzanie i pielęnacja terenów zieleni), part III, edit II, Hortpress Sp. z o.o., Warszawa (2010)

2. Municipal Office in Gliwice, Nursing of trees and shrubs in the light of the Nature Conservation Act (original title in Polish: Pielegnowanie drzew i krzewów w świetle ustawy o ochronie przyrody), https://bip.gliwice.eu/strona=10612, March (2017)

3. H.B. Szczepanowska, Good practices in the development of urban space with green infrastructure, especially with trees (original title in Polish: Dobre praktyki w zakresie zagospodarowania przestrzeni miejskiej zielona infrastruktura, zwłaszcza drzewami) Miasto idealne - miasto zrównoważone, Planowanie przestrzenne terenów zurbanizowanych i jego wpływ na ograniczenie skutków zmian klimatu, edited by Kalinowskiej A., part II, B. Podejście ekosystemowi do miast- usługi na rzecz adaptacji do zmian klimatu, 201-209, Warszawa, ISBN 978-83-917679-6-2, (2015)

4. S. Tombesi, D. Farinelli, M. Molfese, M. Cipolletti, T. Visco, Pruning technique in young high density hedgerow olive orchards. Conference: 7th International Symposium on Olive Growing, Location: San Juan, ARGENTINA, Date: SEP 25-29, 2012. VII INTERNATIONAL SYMPOSIUM ON OLIVE GROWING, Book Series: Acta Horticulturae 1057, 385-390 (2014)

5. V. Adamchuk, V. Bulgakov, N. Skorikov, T. Yezekyan, J. Olt, Developing a new design of wood chopper for grape vine and fruit tree pruning and the results of field testing. Agronomy Research 14 (5), 1519-1529 (2016)

6. A.B. Dias, S. Patrocinio, S. Pereira, T. Brites, V. Pita, J.M.M. Barroso, Evaluation of the use of a disc-saw machine in winter pruning 'Rocha' pears orchards - an account of five years. Conference: 12th International Pear Symposium, Location: Leuven, BELGIUM, Date: JUL 14-18, 2014, XII INTERNATIONAL PEAR SYMPOSIUM, Book Series: Acta Horticulturae 1094, 281-288 (2015)

7. J. Przybylko, The applications of autonomous systems to forestry management. Massachusetts Institute of Technology, http://hdl.handle.net/1721.1/81014 (2013)

8. P.J.C. Stassen, Development of pruning and training systems for higher density peach orchards in South Africa. Conference: 8th International Peach Symposium, Location: Matera, ITALY, Date: JUN 17-20, 2013-2016, VIII INTERNATIONAL PEACH SYMPOSIUM Book Series: Acta Horticulturae 1084, 343-350 (2015)

9. B. Velazquez-Marti, E. Fernandez-Gonzalez, The influence of mechanical pruning in cost reduction, production of fruit, and biomass waste in citrus orchards. APPLIED ENGINEERING IN AGRICULTURE 26 (4), 531-540 (2010)

10. M. Carlini, S. Castellucci, S. Cocchi, A. Manzo, Waste wood biomass arising from pruning of urban green in Viterbo town: energy characterization and potential uses. International Conference on Computational Science and Its Applications: ICCSA 2013, Part II, LNCS 7972, 242-255, DOI: 10.1007/978-3-642-39643-4_19 (2013)

11. G.Q. Luo, D.S. Chandler, L.C.A. Anjos, R.J. Eng, P., Jia, F.L.P. Resende, Pyrolysis of whole wood chips and rods in a novel ablative reactor. FUEL 194, 229-238, DOI: 10.1016/j.fuel.2017.01.010 (2017) 
12. N. Striugas, K. Zakarauskas, A. Džiugys, R. Navakas, R. Paulauskas, An evaluation of performance of automatically operated multi-fuel downdraft gasifier for energy production. Applied Thermal Engineering $\mathbf{7 3}$ (1), 1151-1159 DOI: 10.1016/j.applthermaleng.2014.09.007 (2014)

13. J. Calatrava, J.A. Franco, Using pruning residues as mulch: Analysis of its adoption and process of diffusion in Southern Spain olive orchards. Journal of Environmental Managment 92, (3), 620-629, DOI:10.1016/j.jenvman.2010.09.023 (2011)

14. H.T. Sahin, M.B. Arslan, Properties of orchard pruning and suitability for composite production. Science and Engineering of Composite Materials 20 (4), 337-342 DOI: 10.1515/secm-2012-0033 (2013)

15. D. Timmons, C.V. Mejía, Biomass energy from wood chips: Diesel fuel dependence? Biomass and Bioenergy 34 (9), 1419-1425, DOI: 10.1016/j.biombioe.2010.04.010 (2010)

16. L.J. Naimi, S. Sokhansanj, S. Mani, M. Hoque, T. Bi, A.R. Womac, S. Narayan, Cost and performance of woody biomass size reduction for energy production. CSBE/SCGAB Annual Conference, Edmonton Alberta, July 16 - 19, 2006, paper 06107, 1-13 (2006)

17. R. Abdallah, S. Auchet, P.J. Méausoone, Experimental study about the effects of disc chipper settings on the distribution of wood chip size. Biomass and Bioenergy 35 (2), 843-852, DOI: 10.1016/j.biombioe.2010.11.009 (2011)

18. L.M. Hellström, P.A. Gradin, T. Carlberg, A method for experimental investigation of the wood chipping process. Nordic Pulp \& Paper Research Journal 23 (3), 339-342 (2008)

19. R. Kuryjański, Machining and machine tools (original title in Polish: Obróbka skrawaniem i obrabiarki), Copyright Politechnika Warszawska, ISBN 83-89703-72-6 (2011)

20. K. Orlowski, T. Ochrymiuk, A newly-developed model for predicting cutting power during wood sawing with circular saw blades. Maderas. Cienc. tecnol. 19 (2), 149-162 (2017)

21. W. Spychała, Ł. Łowiński, T. Pawłowski, Z. Zbytek, Simulation research of impast of cutting resistance on machine frame. Journal of Research and Applications in Agricultural Engineering 55 (2), 134-137 (2010)

22. M. Krajnc, B. Dolsak, Computer and experimental simulation of biomass production using drum chipper. International Journal of Simulation Modelling 12 (1), 39-49, ISSN 1726-4529, DOI:10.2507/IJSIMM12(1)4.223 (2013)

23. M. Merhar, B. Bučar, Cutting force variability as a consequence of exchangeable cleavage fracture and compressive breakdown of wood tissue. Wood Science and Technology 46 (5), 965-977, doi:10.1007/s00226-011-0457-4 (2012)

24. C. Nati, R. Spinelli, How blade wear of chippers can affect fuel consumption and wood chip size distribution, Forest engeneering: Meeting the Needs of the Society and the Environment, FORMEC 2010, July 11-14, 2010, Padova - Italy, 1-7 (2010)

25. C. Nati, R. Spinelli, P. Fabbri, Wood chips size distribution in relation to blade wear and screen use. Biomass and Bioenergy 34 (5), 583-587, DOI: 10.1016/j.biombioe.2010.01.005 (2010)

26. R. Spinelli, N. Magagnotti, G. Paletto, C. Preti, Determining the impact of some wood characteristics on the performance of a mobile chipper. Silva Fennica 45 (1), 85-95 ISSN 0037-5330 (2011) 